\title{
PRELIMINARY OBSERVATION OF OCCASIONAL MORTALITY IN THE POPULATION OF FRESHWATER CRAYFISH IN THE PICOS DE EUROPA (ASTURIAS, SPAIN).
}

\author{
F. ROYO (1), G. GONZALEZ-CIENFUEGOS (2), J.L. MUZQUIZ (1)
}

\begin{abstract}
(1) Animal Pathology Department of Veterinary Faculty of University of Zaragoza. C/ iguel Servet $n^{\circ} 177,50013$ ZARAGOZA, Spain. E-mail : muzquiz@ posta.unizar.es

(2) Parque Nacional Picos de Europa, OVIEDO, Asturias.
\end{abstract}

\begin{abstract}
Factors associated with mortality in a population of Austropotamobius italicus, formerly A. pallipes lusitanicus, were monitored during two years in the Natural Park of Picos de Europa. Dead crayfish were submitted to the laboratory for analysis. No mass mortalities occurred during these two years. The number of mortalities was not constant throughout the year, with highest levels observed in May-June and November-December. Over the rest of the year mortality remained low. A high proportion of dead crayfish displayed signs of predation, mainly observed during the months of November and December. Other causes associated with mortality were storms and the process of moulting, especially in June. The presence of Saprolegnia in females during the reproduction season was also observed. Symptoms of Porcelain disease, or the presence of Psorospermium, were not observed during this study.
\end{abstract}

Key-words : Austropotamobius italicus, mortality, diseases.

\author{
OBSERVATION PRÉLIMINAIRE DE LA MORTALITÉ \\ OCCASIONNELLE CHEZ LA POPULATION D'ÉCREVISSES \\ À PICOS DE L'EUROPE (ASTURIAS, ESPAGNE).
}

\section{RÉSUMÉ}

Les facteurs associés avec la mortalité d'une population d'Austropotamobius italicus, anciennement dénommée $A$. pallipes lusitanicus située dans le parc naturel de Picos de l'Europe ont été étudiées durant deux ans. Les écrevisses mortes ont été analysées au laboratoire. Aucune mortalité de masse n'est apparue pendant ces deux ans. Le nombre 
d'écrevisses mortes n'est pas constant pendant l'année, les mois de mai-juin et de novembre-décembre présentent les chiffres les plus élevés de mortalité. Le reste de l'année, la mortalité est basse. Un haut pourcentage des animaux présente des signes de prédation. Cela peut être observé principalement pendant les mois de novembredécembre. D'autres causes telles que les crues et la mue ont été recensées en juin principalement. La présence de Saprolegnia chez les femelles a également été montrée durant la saison de reproduction. La maladie de la porcelaine et la présence de Psorospermium n'ont pas été observées pendant cette étude.

Mots-clés : Austropotamobius italicus, mortalité, maladies.

\section{INTRODUCTION}

The native crayfish of the Iberian Peninsula, Austropotamobius italicus, formerly known as Austropotamobius pallipes lusitanicus (GRANDJEAN et al., 2000), is an endangered species, included in different plans of restoration in Spain (ALONSO et al., 2000). Since 1999, the veterinary service responsible for the natural park of Picos de Europa (Asturias, Spain) has been studying the population of native crayfish which inhabits this area. According to PARDO (1942), this population was probably introduced in the $18^{\text {th }}$ century, and nowadays is part of the ecosystem of this natural park. This population has not suffered mass mortalities caused by pollutants, or loss of habitats due to farming or agricultural activity. Besides it is possible to find crayfish juvenile and adult which are established through a river and a lake, therefore the population seems to be healthy. The park is protected against introduction of exotic crayfish.

The present paper describes and discusses the mortalities which have occasionally occurred in this population over a two year period.

\section{MATERIAL AND METHODS}

The river and lake containing crayfish were monitored every week over two years. Dead crayfish were found, samples were collected and preserved in $70 \%$ alcohol, and afterward submitted for analysis to the Ichthiopathology Laboratory of the Department of Animal Pathology, Veterinary Faculty of the University of Zaragoza.

Firstly, an external examination was done, looking for cuticular damage and other external symptoms such as white or opaque subabdominal muscular tissue, indicative of porcelain disease caused by Thelohania contejani (DIÉGUEZ-URIBEONDO et al., 1997) and presence of external worms of the family Branchiobdellidae (GELDER et al., 1994).

Secondly, soft subabdominal cuticle and gills were dissected and observed microscopically using $\times 400$ magnification. Special attention was paid to the presence of fungal hyphae within the cuticle (CERENIUS et al., 1988) and necrotic areas in the gill. If fresh samples were received, the soft cuticle was cultured in PG1, according to CERENIUS et al. (1988).

Applying these techniques, we have described some findings which could be related with the mortality of each crayfish. In doing so, we have applied the following criteria. When a macroscopic wound was seen, surrounded by a melanized area, and the primary cause was probably a mechanical agent which penetrated into muscular tissue or the cephalothorax cavity, then we have considered that the lesion was caused by the attack of another crayfish or other animal, although bacteria or abiotic conditions could be involved afterwards. For this reason the sample was referenced as " aggression ». Those samples of soft crayfish, which have not been successful in moulting, were referenced as mortalities 
associated with the "moulting » process. If the only observable symptom was the presence of fungal hyphae in the subabdominal cuticle, the mortalities were registered as « fungal » infection. Samples collected after heavy rains, that showed dark gills but no other symptom, were referenced as mortalities associated with " storms ». Samples with epibionts in the gills but no other symptoms were referenced as « epibionts ». A group of crayfish submitted in July of 2001, when high temperatures were reached, showed inflammation of the articulation between thorax and abdomen. These samples were referenced as mortality associated with « bacterial » septicaemia, because in our lab we have found this symptom associated with Aeromonas hydrophila septicaemia, although this bacteria is considered as an opportunistic pathogen (OIDTMANN and HOFFMANN, 1999).

\section{RESULTS}

From December 1999 to December 2001, 103 dead crayfish were collected. Although the total size of the population remains unknown, visual estimations suggest that the total number of individuals has not decreased during this period. The temporal distribution of mortality over the study period is presented in Figure 1. The highest number of samples was submitted in November of 2001, when 21 crayfish were collected. May to July and November-December were the months when most mortalities were registered. Conversely, January to April showed low mortalities, as did the months of August to October, a period of high crayfish activity. The findings registered in the lab, and their relative percentages over the total amount of samples is shown in Figure 2. Aggression was the most frequent associated factor, followed by moulting and storms. No symptoms of porcelain diseases, nor presence of Psorospermium, were observed during the present study.

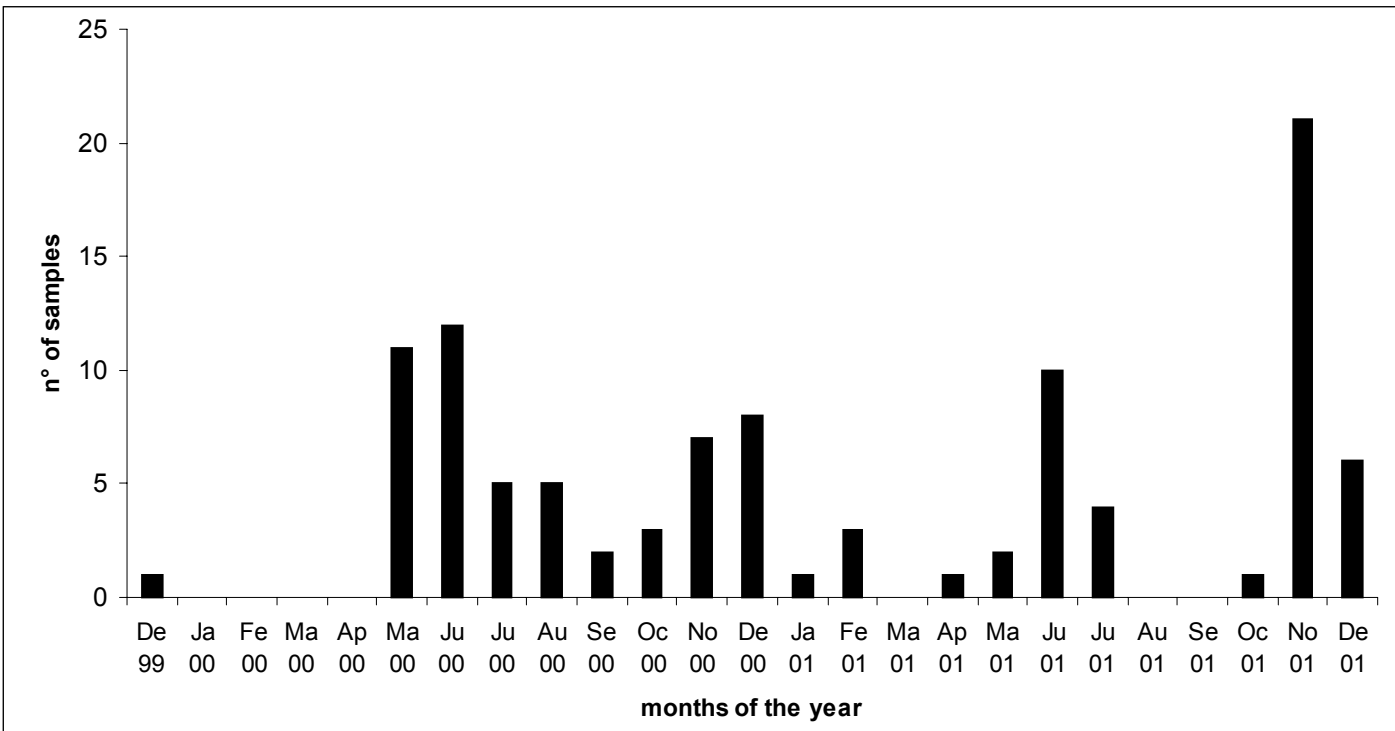

Figure 1

Number of dead individuals per month, collected during two years in Picos de Europa.

\section{Figure 1}

Nombre d'individus morts par mois collectés sur deux ans à Picos de l'Europe. 


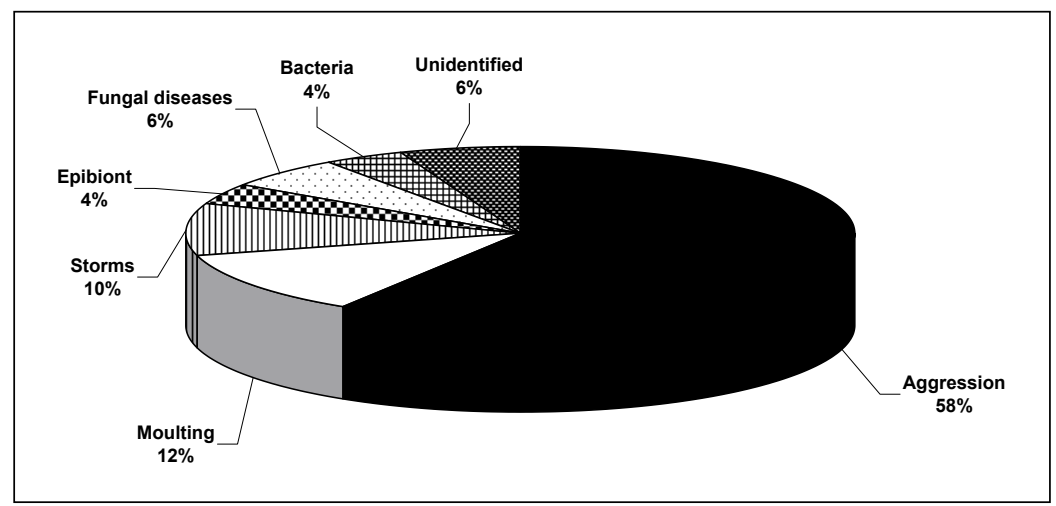

Figure 2

Findings associated with mortality, represented as $\%$ of the individuals analysed.

\section{Figure 2}

Lésions associées à la mortalité, exprimées en pourcentage des individus analysés.

A group of dead females carrying eggs was found in November 2000 and 2001 and these crayfish were received fresh, without alcohol. The cuticle of these females showed the presence of fungal hyphae. When the cuticle was cultured Saprolegnia sp. was isolated. The seasonal distribution of factors registered during two years is shown in Figure 3. Aggressions and other injuries of cuticle happened throughout the year, but the number of cases was greater in November and December. On the other hand, the deaths associated with storms and moulting occurred mainly in May to July. Samples infected by fungi were received in both July and November.

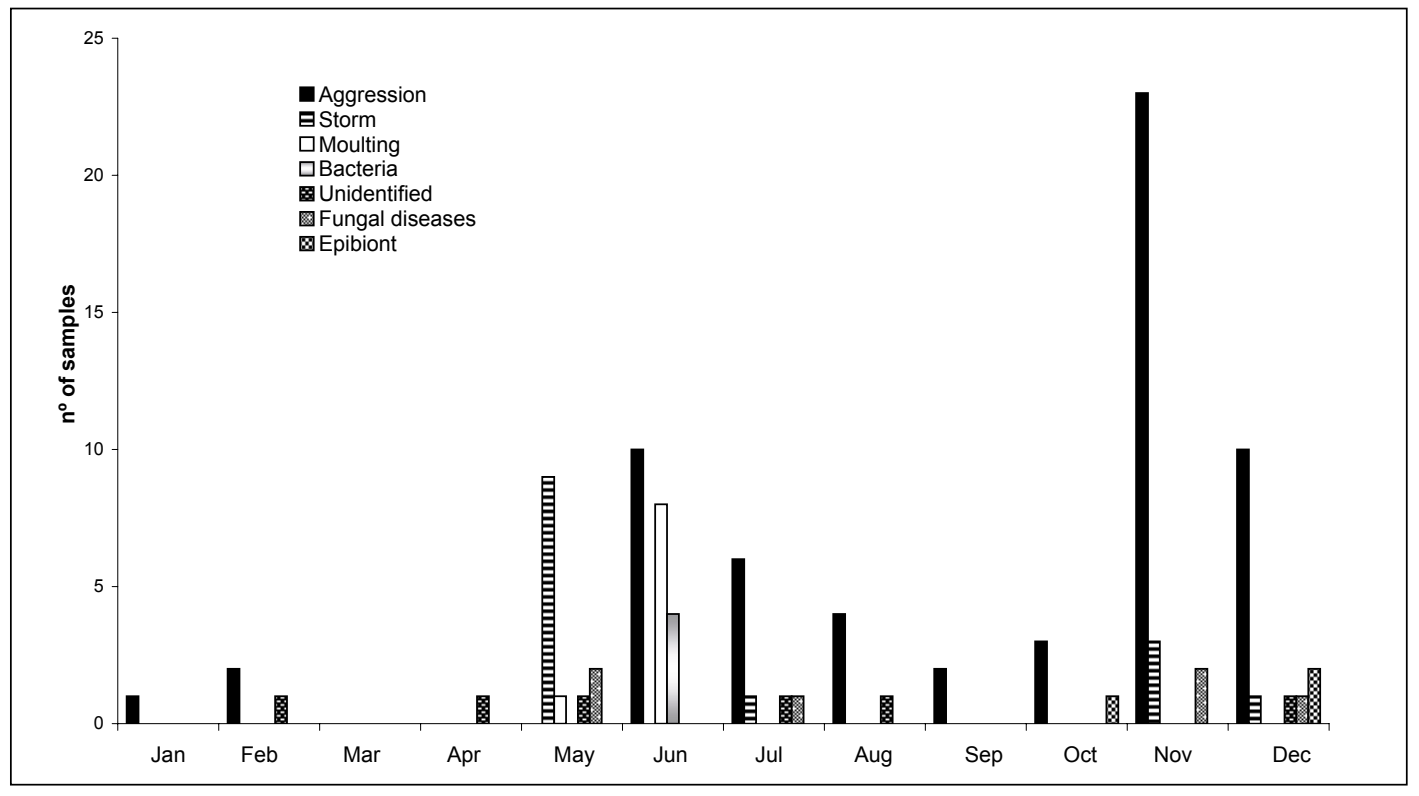

Figure 3

Monthly distribution of factors of mortality for 2000 and 2001.

Figure 3

Distribution mensuelle des facteurs de mortalité durant les années 2000 et 2001. 


\section{DISCUSSION}

These findings indicate a low number of deaths in this population which were not related to pollution or mass mortality diseases. Mortality was not constant but increased during two periods of the year, May-June and November-December. It is not surprising that very low mortality was registered during the months of January to April, when most crayfish remain inactive. More interesting is the fact that low mortality was also registered during the months of August to October, when crayfish exhibit a high activity. For this reason, we suggest that there is no direct relationship between mortality and activity of crayfish. Mortality is instead associated with two critical periods of crayfish physiology, moulting and reproduction. This has been pointed out before by different authors (VEY, 1977; CUELLAR, 1983; ROBINSON et al., 2000).

On the other hand, the time when mortality occurred could be related to the seasonal presence in the area of some kind of predator which remains unidentified. The shape of lesions suggest that the greatest number of mortalities which occurred in November of 2001 were not caused by crayfish (Figure 4). Although bacteria and fungus could infect these wounds and increase the damage of the cuticle, the primary cause of this lesion is presumptively due to a mechanical stress which broke the cuticle. Opposite to " burn spot » diseases or bacterial shell diseases, which are related with high density of crayfish and poor water conditions (EVANS and EDGERTON, 2001), in this case the outbreak took place in the natural population during the month of November, when temperatures started to decrease, and water quality remained optimal.

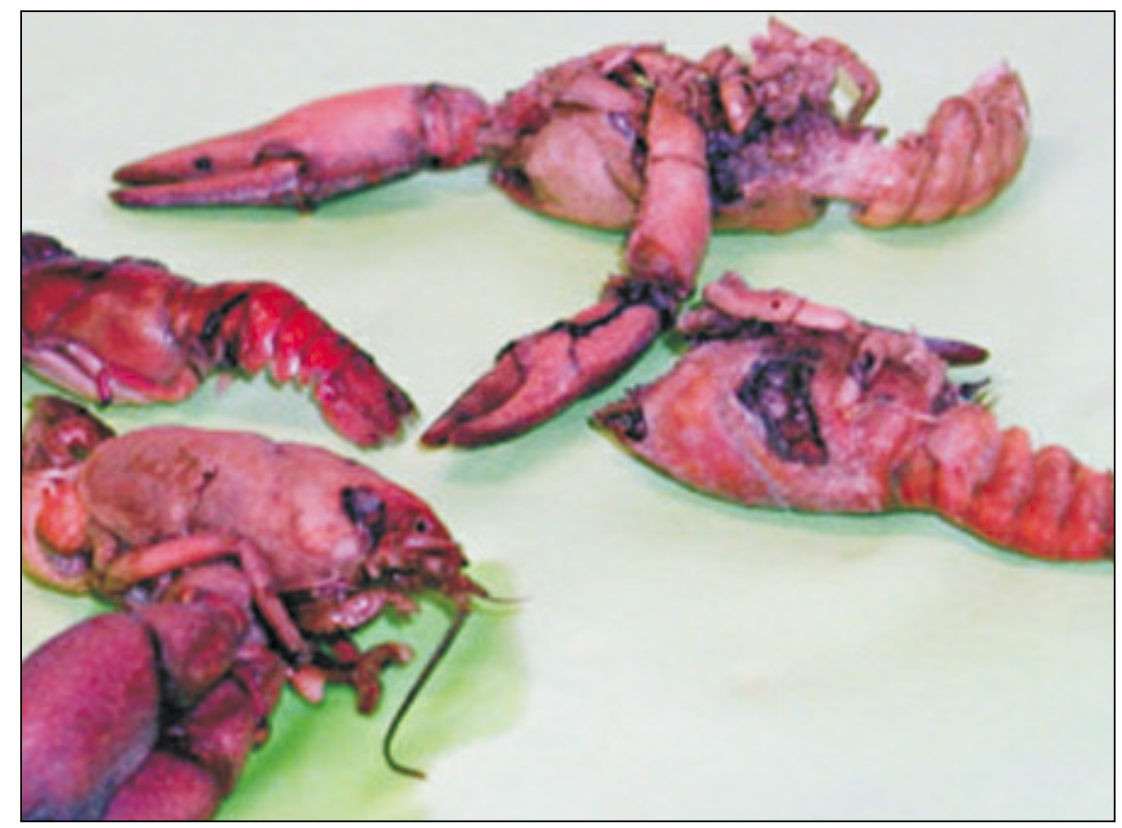

\section{Figure 4}

Lesions in crayfish, caused by a predator in November.

\section{Figure 4}

Lésions sur une écrevisse provoquées par un prédateur et observées en novembre. 
Mortalities associated with moulting were registered in May-June. In this period it was also possible to see mortalities related to storms, and mortalities caused by aggressions. It has been reported that during moulting, aggressive interactions often occur between crayfish (ROBINSON et al., 2000). Some pathogens such as viruses or intracelular bacteria could act in this period (EVANS and EDGERTON, 2001), but the techniques applied did not let us identify them. It is of interest that these mortalities were not an epidemic outbreak, but could be considered as occasional.

In this study we could not demonstrate that the presence of fungal hyphae was a cause of mortality, as the fungus could appear after the death of crayfish. However, there was an interesting group of egg-bearing females which showed only the presence of fungi. This occurred at the end of autumn in both years. From this group, Saprolegnia was isolated, a fungus that has been reported as a pathogen of crayfish (DIÉGUEZ-URIBEONDO et al., 1994). Bacterial diseases were not confirmed using bacteriological culture, and the symptom reported is not definitive to confirm that bacteria was the primary pathogen. In the same way, the presence of epibionts was a common finding in the gills, and only has been referenced when no other symptom could be found. For this reason we cannot suggest any relationship with mortality.

\section{CONCLUSIONS}

This report details occasional mortalities which occurred over a two year period in a well-established crayfish population. Such mortalities had seasonal distributions across the year. The number of crayfish found dead was higher during May-June and NovemberDecember, related to the beginning and the end of the season of crayfish activity. However, mortality was lower in August to October, months when crayfish show highest activity. In the population of Picos de Europa, the main cause of mortality was lesions in the cuticle, that were presumptively caused by the action of an unidentified predator which attacked the population in November. This would also highlight the role that this population plays in the ecosystem of Natural Park. Some physiological events, such as moulting and reproduction, and environmental factors such as storms, were also associated with mortality in the population. Finally, during the reproductive season we have received a group of females which only showed the presence of fungi in the cuticle. In this group, Saprolegnia was isolated. During this two year study, no clinical cases of Porcelain diseases nor presence of Psorospermium was detected. The appearance of higher levels of mortality between the months of January and April, or between August and September, it should be considered as an anomaly.

The next step to describe the pathology present in this population, will be to include histopathology and bacteriology techniques in our study to identify pathogens which are involved with associated factors identified in this study.

\section{ACKOWLEDGEMENTS} samples.

We want to thank the staff of the Natural Park of Picos de Europa for the supply of

Felix Royo is supported by a grant of the Government of Aragon, ref B004-2000, and the work is also financed by the Government of Aragon within the project "Plan de Recuperación del Cangrejo Autóctono, Austropotamobius pallipes, en los ríos de Aragón » con ref: PO 17/ 99-AV. 


\section{REFERENCES}

ALONSO F., TEMINO C., DIÉGUEZ-URIBEONDO J., 2000. Status of the white-clawed crayfish, Austropotamobius pallipes (Lereboullet, 1858), in Spain: distribution and legislation. Bull. Fr. Pêche Piscic., 356, 31-53.

CERENIUS L., SÖDERHÄLL K., PERSSON M., AJAXON A., 1988. The crayfish plague fungus Aphanomyces astaci - diagnosis, isolation and pathobiology. Freshwater Crayfish, 7, 131-144.

CUELLAR L., 1983. Enfermedades Infecto-contagiosas del cangrejo de río en España- La peste micótica del cangrejo. Jornadas de Estudio Sobre el Cangrejo de Río. Exca. Diputación Provincial de Burgos, 39-57.

DIÉGUEZ-URIBEONDO J., CERENIUS L., SÖDERHÄLL K., 1994. Saprolegnia parasitica and its virulence on three different species of crayfish. Aquaculture, 120, 219-228.

DIÉGUEZ-URIBEONDO J., PINEDO-RUIZ J., MUZQUIZ J.L., 1997. Thelohania contejeani in the province of Alava, Spain. Bull. Fr. Pêche Piscic., 347, 749-752.

EVANS L.H., EDGERTON B.F., 2001. Pathogens, Parasites and Commensals. In : Biology of Fresh Water Crayfish, HOLDICH (ed.), Blackwell Science, 377-438.

GELDER S.R., DELMASTRO G.B., FERRAGUTI M., 1994. A report on branchiobdellidans (Annelida: Clitellata) and a taxonomic key to the species in northern Italy, including the first record of Cambarincola mesochoreus on the introduced American red swamp crayfish. Boll. Zool., 61, 179-183.

GRANDJEAN F., HARRIS J., SOUTY-GROSSET C., CRANDALL K.A., 2000. Systematics of the european endangered crayfish species Austropotamobius pallipes (Decapoda: Astacidae). J. Crust. Biol., 20, 522-529.

OIDTMANN B., HOFFMANN R.W., 1999. Bacteriology investigations on crayfish. Freshwater Crayfish, 12, 288-302.

PARDO L., 1942. El cangrejo. (Astacicultura elemental). Ministerio de Agricultura Sección de Prensa y Propaganda (ed.), Madrid, Spain.

ROBINSON C.A., THOM T.J., LUCAS M.C., 2000. Ranging behaviour of a large freshwater invertebrate, the white-clawed crayfish Austropotamobius pallipes. Freshwater Biology, 44, 509-521.

VEY A., 1977. Studies on pathology on crayfish under rearing conditions. Freshwater crayfish, 3, 311-319. 